\title{
Pengaruh Penerapan PSAK 45 dan Ketepatwaktuan Penyampaian Laporan Keuangan terhadap Akuntabilitas Laporan Keuangan Organisasi Nirlaba
}

\author{
Olivia Lungit Astari Putri ${ }^{*}$, Sri Ayem² \\ ${ }^{1,2}$ Universitas Sarjanawiyata Tamansiswa \\ lungitastari@gmail.com, sriayemfeust@gmail.com
}

\author{
*Penulis Korespondensi \\ Diajukan : 25 Juni 2021 \\ Disetujui : 15 Juli 2021 \\ Dipublikasi : 1 Agustus 2021
}

\begin{abstract}
Non-profit organizations/institutions need to comply with regulations in managing financial reports. The purpose of this study was to examine the impact of using PSAK No. 45 and timely submission of financial reports to accountability for these financial statements. The population used is the Yogyakarta Special Region Social Foundation. Sampling using purposive sampling. This research is quantitative with primary data in the form of questionnaires and multiple linear regression analysis methods to test hypotheses. The results found in this study are the application of PSAK No. 45 partially have a positive and significant impact on the accountability of financial statements, and the timeliness of the submission of financial statements partially has a positive and significant impact on the accountability of financial statements. In addition, the application of PSAK No. 45 and the timely submission of financial reports simultaneously or simultaneously also affects the accountability of financial statements by $43.7 \%$. So, every non-profit organization must apply accounting standards in its financial statements and these financial statements must be submitted in a timely manner to be accountable. This study applies compliance theory to prove the research results and support the authors' ideas.
\end{abstract}

Keywords: Accountability, PSAK No. 45, Timeliness

\section{PENDAHULUAN}

Organisasi nirlaba atau nonlaba didefinisikan sebagai institusi yang tidak memiliki tujuan untuk memperoleh laba, melainkan bertujuan untuk melakukan kegiatan-kegiatan sosial atau kemanusiaan. Meskipun organisasi tersebut bersifat nirlaba, namun tetap berkewajiban membuat laporan keuangan yang akuntabel. Laporan keuangan harus disusun berdasarkan standar akuntansi keuangan dan harus disampaikan secara tepat waktu agar laporan keuangan tersebut dapat dikatakan akuntabel.

Melalui website senyumkita.com, laporan keuangan yayasan tahun 2017 belum sinkron dengan laporan keuangan pada kaidah akuntansi yang berlaku bagi organisasi nirlaba yaitu PSAK No. 45. Laporan keuangan organisasi nirlaba yang diatur dalam PSAK 45 mencakup laporan aktivitas, neraca, CALK, dan laporan arus kas. Sedangkan, dalam laporan keuangan Yayasan Senyum Kita tahun 2017, hanya laporan arus kas serta pendapatan dan pengeluaran yang ditampilkan. Hal ini dapat dikatakan bahwa laporan keuangan yayasan tersebut kurang akuntabel karena tidak sesuai dengan standar akuntansi. 
Berdasarkan fenomena di atas, Di Indonesia masih terdapat organisasi nirlaba seperti yayasan yang belum menggunakan standar pelaporan sesuai UU No. 28 Tahun 2004 Tentang Yayasan. Jadi, yayasan tersebut tidak menerapkan PSAK 45 dalam pelaporan keuangannya sehingga tidak akuntabel, sedangkan akuntabilitas pada organisasi sangat penting. Setiap organisasi wajib menyampaikan laporan keuangannya tepat waktu sesuai dengan batas tanggal serta akuntabel, sama halnya dengan organisasi nirlaba. Yayasan Sosial harus menyampaikan laporan keuangan setiap tahunnya. Pelaporan keuangan dilakukan agar terjadi transparansi dana anggota. Sedangkan, bentuk-bentuk dalam laporan keuangan juga dapat mempengaruhi keefektifan penghitungan dan penyampaian laporan keuangan yayasan. Menurut _(Sucipto \& Noor, 2019) Ketepatan waktu adalah faktor vital dalam menyajikan informasi terkait. Jadi, jika laporan keuangan yang tertunda dilaporkan kepada anggota organisasi, informasi yang terkandung di dalamnya tidak akan relevan dan akuntabilitas laporan keuangan tidak akan maksimal. Akuntabilitas merupakan pertanggungjawaban dalam pengelolaan laporan keuangan secara transparansi dan wajar. Sehingga pembuat laporan keuangan maupun organisasi harus dapat mempertanggungjawabkan laporan keuangan tersebut. Mereka harus mampu menjelaskan asal dana atau uang yang tertera dalam laporan keuangan tersebut, serta mampu menjelaskan mengenai pengeluaran dana pada laporan keuangan tersebut.

Motivasi peneliti melakukan penelitian ini adalah jarangnya dilakukan penelitian serupa. Berdasarkan penelitian-penelitian sebelumnya seperti yang dilakukan oleh (Anand, 2018) dan _(Setiawan, Rahman, \& Hidayati, 2021), masih banyak instansi yang belum mengimplementasikan PSAK 45 dalam penyusunan laporan keuangan, bahkan tidak disampaikan secara tepat waktu. Ini menyebabkan laporan keuangan kurang akuntabel sedangkan akuntabilitas laporan keuangan sangat penting. Oleh karena itu, peneliti ingin membuktikan pentingnya standar akuntansi dan penyampaian laporan keuangan secara tepat waktu untuk meningkatkan akuntabilitas.

Referensi penelitian terdahulu yang digunakan pada penelitian ini yaitu penelitian yang dilakukan oleh _(Anand, 2018) dan _(Setiawan, Rahman, \& Hidayati, 2021). Perbedaan penelitian ini dengan kedua penelitian tersebut adalah peneliti menambahkan ketepatwaktuan penyampaian laporan keuangan sebagai variabel X2 dan akuntabilitas laporan keuangan sebagai variabel Y. Selain itu, peneliti menggunakan metode penelitian kuantitatif dengan sumber data primer yaitu kuesioner, berbeda dengan penelitian _(Anand, 2018),_(Rusdiyanto, 2016), dan_(Indrarini \& Nanda, 2017). Pada penelitian_(Anand, 2018) menggunakan metode penelitian kualitatif dengan data primer seperti pengamatan dan wawancara, serta kuantitatif data sekunder yang berupa laporan keuangan yayasan. Sama halnya dengan penelitian _(Rusdiyanto, 2016) yang mengumpulkan data memakai data primer melalui wawancara dan data sekunder berupa laporan keuangan, serta penelitian (Indrarini \& Nanda, 2017) yang menggunakan metode kualitatif deskriptif. Penelitian ini penting dilakukan untuk memperbaharui penelitian-penelitian sebelumnya agar hasil yang ditemukan lebih valid dengan menggunakan sampel yang lebih banyak dan menggunakan metode penelitian kuantitatif.

\section{Teori Kepatuhan (Compliance Theory)}

\section{STUDI LITERATUR}

Konsistensi atau kepatuhan ialah asal dari kata "patuh" dimana bisa diartikan sebagai menjaga suatu standar atau standar yang berlaku. Menurut_(Sucipto \& Noor, 2019), teori kepatuhan bisa memberi seseorang untuk lebih setuju dengan pedoman relevan, seperti organisasi yang mencoba mengirimkan laporan keuangan dengan cara tepat waktu karena merupakan suatu komitmen, penyampaian yang tepat waktu, dan juga sangat membantu para pengguna laporan keuangan. Teori kepatuhan dapat mengajarkan emiten 
berupaya tepat waktu dalam melaporkan laporan keuangan karena selain mewujudkan tanggung jawab untuk menyampaikan tepat waktu juga akan lebih berguna untuk pemakai laporan keuangan_(Marfuah, Sakilah, \& Prasetyo, 2021).

\section{Organisasi Nirlaba}

Organisasi/lembaga nirlaba dapat didefinisikan sebagai lembaga yang bukan bertujuan memperoleh laba, melainkan untuk melakukan kegiatan-kegiatan sosial atau kemanusiaan. Sebagaimana ditunjukkan oleh_(Marlinah \& Ibrahim, 2018), lembaga nirlaba adalah lembaga yang didirikan oleh orang-orang pada umumnya, dan aset dalam lembaga tersebut berasal dari masyarakat umum, sehingga diharapkan untuk masyarakat umum. Organisasi nirlaba merupakan suatu organisasi yang bertujuan untuk mendukung dan melayani kepentingan publik yang tidak berhubungan dengan perdagangan_(Hatta, 2021).

\section{Pernyataan Standar Akuntansi Keuangan (PSAK) No. 45}

PSAK 45 yaitu kaidah untuk mengatur laporan keuangan dalam asosiasi non-profit. Jika kaidah ini digunakan oleh organisasi nirlaba sebagai standar pelaporan keuangan, maka laporan keuangannya akan memiliki relevansi, daya banding yang tinggi, dan mudah untuk dipahami. Jika organisasi nirlaba menggunakan kaidah tersebut pada laporan keuangan maka laporan keuangan tersebut akan mempunyai kegunaan, daya banding tinggi, dan mudah dipahami. PSAK 45 merupakan standar akuntansi untuk menyediakan informasi yang relevan guna memenuhi kepentingan para penyumbang, anggota organisasi, kreditur, dan pihak lain yang menyediakan sumber daya bagi organisasi nirlaba (Sunardi, Ambarwati, Rusmawati, Riszaldi, \& Krisnanto, 2021)

\section{Ketepatwaktuan Penyampaian Laporan Keuangan}

Ketepatan waktu saat menyampaikan laporan keuangan adalah waktu yang digunakan dalam menyampaikan atau melaporkan laporan keuangan. Sebagaimana ditunjukkan oleh_(Nurmiati, 2016), ketepatwaktuan pelaporan keuangan adalah selang waktu melaporkan laporan keuangan tahunan yang diperiksa kepada masyarakat umum dari tanggal akhir pembukuan organisasi (31 Desember) sampai dengan tanggal akomodasi ke Bapepam-LK. Informasi laporan keuangan harus disampaikan tepat waktu untuk menghindari hilangnya relevansi informasi yang terdapat di dalamnya, sehingga keputusan ekonomi dapat segera diambil_(Marfuah, Sakilah, \& Prasetyo, 2021).

\section{Akuntabilitas Laporan Keuangan}

Akuntabilitas merupakan pertanggungjawaban dalam pengelolaan laporan keuangan secara transparansi dan wajar. Hal ini berarti pembuat laporan keuangan maupun organisasi harus dapat mempertanggungjawabkan laporan keuangan tersebut, artinya mampu menjelaskan asal dana atau uang yang tertera dalam laporan keuangan tersebut, serta mampu menjelaskan mengenai pengeluaran dana pada laporan keuangan tersebut.

Menurut_(Athifah, Bayinah, \& Bahri, 2018), Akuntabilitas berasal dari kata Latin accomptare yang berarti dapat diandalkan, khususnya dari kata esensial computare yang bermaksud untuk mempertimbangkan. Dalam bahasa inggris itu adalah tanggung jawab yang menyiratkan tugas atau kondisi untuk diwakili atau kondisi untuk dianggap bertanggung jawab. Accountability is a model of 3 dimensions: responsibility, transparency, answerability_(Zahavy \& Leonenko, 2019).

\section{Pengembangan Hipotesis}

Pengaruh Penerapan PSAK No. 45 Terhadap Akuntabilitas Laporan Keuangan

Lembaga nirlaba harus patuh terhadap standar atau peraturan yang dibuat oleh 
pemerintah, terutama laporan keuangannya harus menerapkan standar akuntansi yang berlaku agar dapat dikatakan akuntabel. Jika PSAK 45 diterapkan pada laporan keuangan organisasi nirlaba, maka dapat dikatakan akuntabel karena sudah sesuai dengan standar pelaporan keuangan. Penelitian dimana telah dilaksanakan oleh_(Sulistiana, 2018) mengatakan jika saat menyusun laporan keuangan menggunakan standar akuntansi seharusnya meningkatkan akuntabilitas publik. Artinya PSAK No. 45 berdampak positif terhadap akuntabilitas laporan keuangan. Penggunaan PSAK No. 45 dapat memenuhi kepentingan pengguna laporan keuangan karena informasi-informasi yang terkandung di dalamnya menjadi lengkap dan dapat dipertanggungjawabkan, serta bisa digunakan sewaktu-waktu jika pengguna laporan keuangan membutuhkan, sehingga hal ini berarti bahwa laporan keuangan bersifat akuntabel. Untuk memenuhi kepentingan pengguna laporan keuangan yang mengharapkan sebuah pengelolaan dan pelaporan keuangan yang transaparan dan akuntabel, pemerintah mengatur pengelolaan dan pelaporan keuangan dalam PSAK No. 45 _(Setiawan, Rahman, \& Hidayati, 2021).

Maka dapat disimpulkan bahwa penerapan PSAK No. 45 berdampak positif pada akuntabilitas laporan keuangan. Hal ini sejalan dengan penelitian yang telah dilakukan oleh (Rusdiyanto, 2016) dan _(Suryani, Dewi, \& Herawati, 2017) yang menunjukkan bahwa penerapan PSAK No. 45 berdampak pada akuntabilitas laporan keuangan.

H1: Penerapan PSAK No. 45 berpengaruh positif pada akuntabilitas laporan keuangan

\section{Pengaruh Ketepatwaktuan Penyampaian Laporan Keuangan Terhadap Akuntabilitas Laporan Keuangan}

Akuntabilitas laporan keuangan organisasi dapat tercapai jika dalam menyampaikan laporan keuangan tersebut tidak mengalami keterlambatan penyampaian dan disajikan sesuai dengan standar akuntansi. Dalam eksplorasi _(Suparwan, Sujana, \& Yuniarta, 2018) menunjukkan bahwa kecukupan pengungkapan laporan keuangan memiliki dampak positif dan besar terhadap kualitas pertanggungjawaban laporan tersebut. Jadi dapat dikatakan bahwa ketepatwaktuan penyampaian laporan yang termasuk dalam kecukupan pengungkapan laporan keuangan dapat mempengaruhi akuntabilitas laporan keuangan. Laporan keuangan sangat penting bagi kebutuhan organisasi, maka laporan keuangan yang disampaikan tepat waktu dapat digunakan sebagai pengambilan keputusan untuk organisasi. Hal ini berarti bahwa akuntabilitas semakin baik jika laporan keuangan disampaikan secara tepat waktu. Akuntabilitas keuangan akan semakin membaik jika didukung oleh suatu system akuntansi yang menghasilkan informasi yang akurat, handal, tepat waktu, serta dapat dipertanggungjawabkan _(Lusdiani \& Ta'dung, 2020).

Maka dapat disimpulkan bahwa ketepatwaktuan penyampaian laporan keuangan berdampak positif pada akuntabilitas laporan keuangan. Hal ini sejalan dengan penelitian (Indrarini \& Nanda, 2017) yang menunjukkan penyajian laporan keuangan tepat waktu berdampak positif pada akuntabilitas laporan keuangan.

$\mathrm{H} 2$ : Ketepatwaktuan penyampaian laporan keuangan berdampak positif pada akuntabilitas laporan keuangan

\section{Sifat Penelitian}

\section{METODE}

Penelitian ini menggunakan metode kuantitatif dan menggunakan data asli berupa kuesioner, kemudian kuesioner didistribusikan ke bagian keuangan Yayasan Sosial Daerah Istimewa Yogyakarta. 


\section{Definisi Operasional Variabel}

Penerapan PSAK No. 45

PSAK No. 45 adalah standar untuk mengatur laporan keuangan lembaga non-profit. Laporan keuangan lembaga non-profit berisi penjelasan tentang laporan aktivitas, arus kas, CALK, dan neraca.

Tabel 1. Pengukuran Variabel Penerapan PSAK No. 45

\begin{tabular}{|c|c|c|c|}
\hline Variabel & Definisi Operasional & Indikator & Skala \\
\hline $\begin{array}{l}\text { Penerapan } \\
\text { PSAK } 45\end{array}$ & $\begin{array}{l}\text { PSAK No. } 45 \text { ialah standar akuntansi yang } \\
\text { mengatur mengenai laporan keuangan } \\
\text { organisasi nirlaba. }\end{array}$ & $\begin{array}{l}\text { 1. Pengetahuan } \\
\text { dan Kepatuhan } \\
\text { 2. Bentuk dan } \\
\text { format PSAK } \\
\text { No. } 45\end{array}$ & Likert \\
\hline
\end{tabular}

Sumber: PSAK Nomor 45

\section{Ketepatwaktuan Penyampaian Laporan Keuangan}

Ketepatwaktuan saat menyampaikan laporan keuangan adalah waktu digunakan untuk menyampaikan atau melaporkan laporan keuangan berdasarkan waktu tertentu yang telah ditentukan. Laporan keuangan harus disampaikan tepat waktu agar laporan keuangan tersebut akuntabel dan dapat dijadikan sebagai pengambilan keputusan.

Tabel 2. Pengukuran Variabel Ketepatwaktuan Penyampaian Laporan Keuangan

\begin{tabular}{|c|c|c|c|}
\hline Variabel & Definisi Operasioanl & Indikator & Skala \\
\hline $\begin{array}{l}\text { Ketepatwaktuan } \\
\text { Penyampaian } \\
\text { Laporan Keuangan }\end{array}$ & \begin{tabular}{llr} 
Ketepatwaktuan & \multicolumn{2}{c}{ penyampaian } \\
laporan & keuangan adalah & waktu \\
yang & digunakan & untuk \\
menyampaikan laporan keuangan & \multicolumn{1}{l}{ berdasarkan waktu tertentu yang } \\
telah ditentukan.
\end{tabular} & 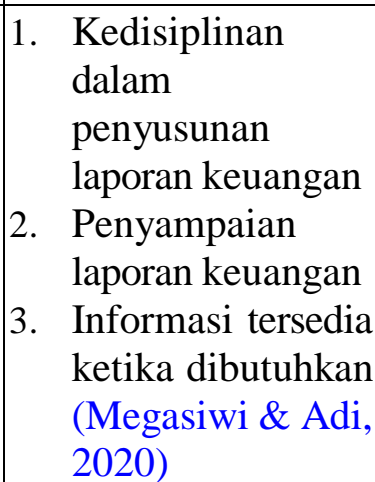 & Likert \\
\hline
\end{tabular}

\section{Akuntabilitas Laporan Keuangan}

Akuntabilitas merupakan pertanggungjawaban dalam pengelolaan laporan keuangan secara transparansi dan wajar. Hal ini berarti bahwa laporan keuangan harus dapat dipertanggungjawabkan agar tidak terjadi kecurangan laporan keuangan dalam organisasi.

Tabel 3. Pengukuran Variabel Akuntabilitas Laporan Keuangan

\begin{tabular}{|c|l|l|l|l|}
\hline Variabel & \multicolumn{2}{|c|}{ Definisi Operasional } & \multicolumn{1}{|c|}{ Indikator } & Skala \\
\hline Akuntabilitas & Akuntabilitas laporan keuangan & 1. & Akuntabilitas & Likert \\
Laporan Keuangan & merupakan pertanggungjawaban & kejujuran & \\
& dalam pengelolaan laporan & 2. & Akuntabilitas & \\
keuangan secara transparansi dan & proses & \\
wajar & 3. & Akuntabilitas \\
& & program & \\
& 4. & Transparansi & \\
\hline
\end{tabular}




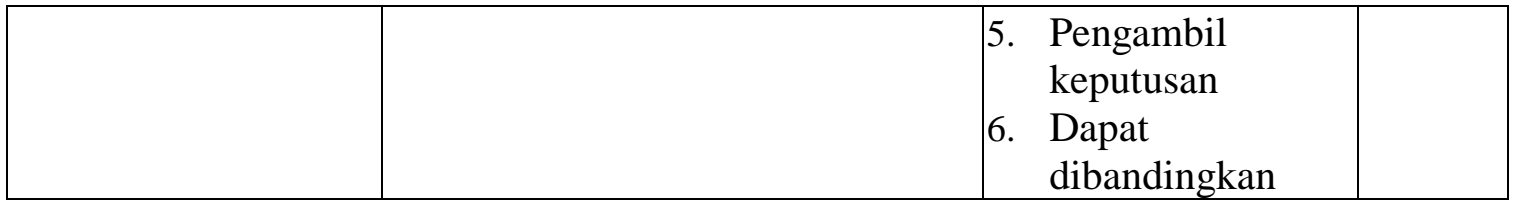

Sumber: (Mardiasmo, 2018)

\section{Populasi, Sampel, dan Teknik Pengambilan Sampel}

Populasi pada penelitian ini ialah Yayasan Sosial di Daerah Istimewa Yogyakarta. Jumlah populasi tidak dapat diketahui secara pasti, sehingga peneliti menggunakan teori Roscoe untuk menentukan jumlah sampel. Penentuan sampel ini sudah banyak dilakukan pada penelitian-penelitian, seperti penelitian yang dilakukan oleh _(Lewis \& Sitompul, 2021) Adapun jumlah sampel ditentukan berdasarkan pada pendapat roscoe karena populasi tidak diketahui dengan pasti. Menurut Roscoe dalam _(Sugiyono, 2019), jika penelitian mengarah pada multivariate, maka total sampel yang diuji setidaknya sepuluh kali jumlah variabel. Peneliti menggunakan 3 variabel dalam penelitian sehingga membutuhkan minimal 30 responden. Purposive sampling ialah teknik dalam pengambilan sampel yang digunakan dalam penelitian dengan melakukan ketentuan yaitu yayasan sosial yang masih aktif pada tahun 2020 dan 2021, serta yayasan sosial yang sudah membuat laporan keuangan. Peneliti menggunakan sampel 31 responden bagian akuntansi yayasan yang terdiri dari yayasan sosial yang berada di Kabupaten Bantul, Kabupaten Sleman, Kabupaten Kulonprogo, serta Kotamadya Yogyakarta.

\section{Sumber dan Metode Pengumpulan Data}

Penelitian ini memakai sumber data primer berupa kuesioner. Metode pengumpulan data dilakukan dengan menyebarkan kuesioner berupa angket dan google forms kepada bagian keuangan Yayasan Sosial Daerah Istimewa Yogyakarta (DIY).

\section{Metode Analisis Data}

Data pada penelitian ini diolah menggunakan software SPSS 26 dan menggunakan metode analisis regresi linear berganda dengan persamaan $Y^{\prime}=a+b_{1} X_{1}+b_{2} X_{2}$.

\section{Uji Kualitas Data}

\section{HASIL}

Tabel 4. Uji Validitas

\begin{tabular}{|l|l|c|c|c|c|}
\hline No & \multicolumn{1}{|c|}{ Variabel/Indikator } & $\begin{array}{c}\text { Pearson } \\
\text { Correlation }\end{array}$ & $\begin{array}{c}\text { r- } \\
\text { tabel }\end{array}$ & Sig. & Keterangan \\
\hline 1 & Penerapan PSAK No.45 & & & & \\
\hline & Butir 1 & 0,651 & 0,456 & 0,000 & Valid \\
& Butir 2 & 0,592 & 0,456 & 0,000 & Valid \\
& Butir 3 & 0,840 & 0,456 & 0,000 & Valid \\
& Butir 4 & 0,871 & 0,456 & 0,000 & Valid \\
& Butir 5 & 0,904 & 0,456 & 0,000 & Valid \\
& Butir 6 & 0,893 & 0,456 & 0,000 & Valid \\
& Butir 7 & 0,915 & 0,456 & 0,000 & Valid \\
& Ketepatwaktuan Penyampaian Laporan & & & & \\
\hline & Keuangan & 0,765 & 0,456 & 0,000 & Valid \\
\hline & Butir 1 & 0,657 & 0,456 & 0,000 & Valid \\
\hline
\end{tabular}




\begin{tabular}{|l|l|c|c|c|c|}
\hline \multirow{2}{*}{ Butir 3 } & 0,765 & 0,456 & 0,000 & Valid \\
& Butir 4 & 0,854 & 0,456 & 0,000 & Valid \\
& Butir 5 & 0,716 & 0,456 & 0,000 & Valid \\
\hline & Akuntabilitas Laporan Keuangan & & & & \\
\hline & Butir 1 & 0,703 & 0,456 & 0,000 & Valid \\
& Butir 2 & 0,764 & 0,456 & 0,000 & Valid \\
Butir 3 & 0,580 & 0,456 & 0,000 & Valid \\
Butir 4 & 0,610 & 0,456 & 0,000 & Valid \\
Butir 5 & 0,617 & 0,456 & 0,000 & Valid \\
Butir 6 & 0,849 & 0,456 & 0,000 & Valid \\
Butir 7 & 0,476 & 0,456 & 0,000 & Valid \\
\hline
\end{tabular}

Sumber: Data primer diolah, 2021

Tabel 5. Uji Reliabilitas

\begin{tabular}{|c|l|c|c|}
\hline No & \multicolumn{1}{|c|}{ Variabel } & Cronbach's Alpha & Keterangan \\
\hline 1 & Penerapan PSAK No. 45 & 0,914 & Reliabel \\
\hline 2 & Ketepatwaktuan Penyampaian Laporan Keuangan & 0,814 & Reliabel \\
& & & \\
\hline 3 & Akuntabilitas Laporan Keuangan & 0,788 & Reliabel \\
\hline
\end{tabular}

Sumber: Data primer diolah, 2021

Pengujian kualitas data meliputi uji validitas dan uji reliabilitas. Menurut hasil uji validitas dapat dikatakan bahwa semua pertanyaan pada kuesioner valid, karena nilai pearson correlation pada setiap pernyataan melebihi nilai $\mathrm{r}$ tabel, dan nilai signifikansi tidak melebihi nilai alpha 0,05 . Berdasarkan hasil uji reliabilitas dapat dinyatakan reliabel karena dibuktikan dengan nilai cornbach's alpha pada variabel-variabel lebih dari 0,600.

\section{Analisis Data \\ Statistik Deskriptif}

Tabel 6. Uji Statistik Deskriptif

\begin{tabular}{|l|c|c|c|c|c|}
\hline & $\mathbf{N}$ & Minimum & Maksimum & Mean & $\begin{array}{c}\text { Std. } \\
\text { Deviation }\end{array}$ \\
\hline Penerapan PSAK No. 45 & 31 & 18 & 35 & 29,45 & 4,795 \\
\hline $\begin{array}{l}\text { Ketepatwaktuan } \\
\text { Penyampaian } \\
\text { Laporan Keuangan }\end{array}$ & 31 & 15 & 25 & 21,26 & 2,768 \\
\hline $\begin{array}{l}\text { Akuntabilitas Laporan } \\
\text { Keuangan }\end{array}$ & 31 & 26 & 35 & 30,29 & 2,759 \\
\hline
\end{tabular}

Sumber: Data primer diolah, 2021

Menurut hasil uji statistik deskriptif bisa disimpulkan jika jumlah data $(\mathrm{N})$ dalam penelitian ini adalah 31. Rata-rata yang dimiliki oleh variabel penerapan PSAK No. 45 adalah 29,45 dan standar deviasi 4,795, nilai rata-rata variabel ketepatwaktuan penyampaian laporan keuangan 21,26 dan standar deviasi 2,768, serta nilai rata-rata variabel akuntabilitas laporan keuangan 30,29 dan standar deviasi 2,759. 
Owner: Riset \& Jurnal Akuntansi

e-ISSN : 2548-9224|p-ISSN : 2548-7507

Volume 5 Nomor 2, Agustus 2021

Uji Asumsi Klasik

Uji Normalitas

Tabel 7. Uji Normalitas

\begin{tabular}{|l|l|c|}
\hline & & Unstandardized Residual \\
\hline N & & 31 \\
\hline Normal Parameters & a.b & Mean \\
& Std. Deviation &, 0000000 \\
Most Extreme & Absolute &, 07067542 \\
Differences & Positive &, 146 \\
& Negative &, 146 \\
\hline Kolmogorov Smirnov & &,- 117 \\
\hline Z & &, 146 \\
\hline Asymp. Sig. (2-tailed) & &, $093^{c}$ \\
\hline
\end{tabular}

Sumber: Data primer diolah,2021

Menurut hasil uji normalitas bisa dikatakan jika variabel-variabel tersebut berdistribusi normal. Hal ini disebabkan nilai Kolmogorov-Smirnov sebesar 0,146 dan Asymp. Sig lebih dari 0,05 yaitu 0,093.

\section{Uji Multikolonearitas}

Tabel 8. Uji Multikolonearitas

\begin{tabular}{|l|c|c|}
\hline & $\begin{array}{c}\text { Collinearity } \\
\text { Tolerance }\end{array}$ & Statistics VIF \\
\hline Penerapan PSAK No. 45 & 0,838 & 1,194 \\
\hline Ketepatwaktuan Penyampaian Laporan Keuangan & 0,838 & 1,194 \\
\hline
\end{tabular}

Sumber: Data primer diolah, 2021

Dari tabel tersebut bisa dikatakan jika tidak terjadi multikolinearitas pada penelitian ini, disebabkan nilai tolerance penerapan PSAK No. 45 adalah 0,838 > 0,10 dan nilai VIF $1,194<10$. Sedangkan nilai tolerance ketepatwaktuan penyampaian laporan keuangan sebesar $0,838>0,10$ dan nilai VIF $1,194<10$.

\section{Uji Heteroskedastisitas}

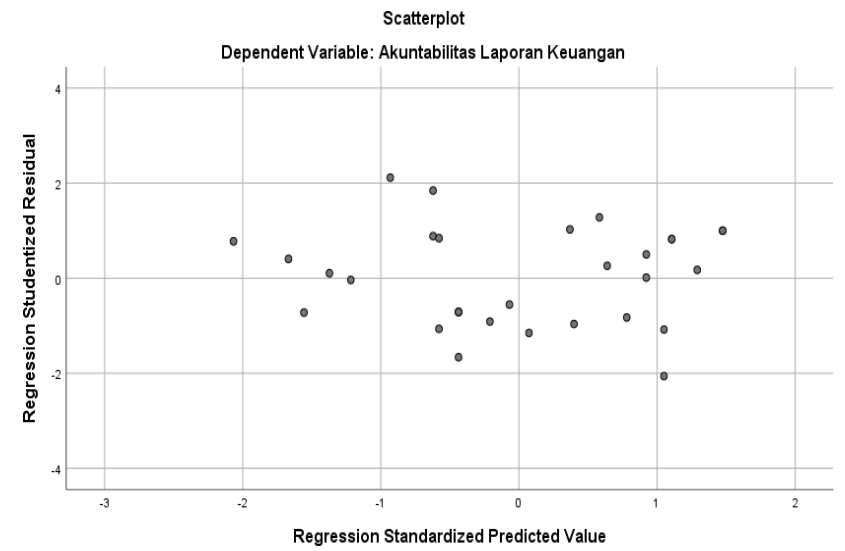

Gambar 2. Uji Heteroskedastisitas

Sumber: Data primer diolah, 2021 
Menurut grafik tersebut, bisa disimpulkan jika tidak terjadi heteroskedastisitas dalam penelitian karena pola yang ditunjukkan pada grafik ini tidak jelas, serta titik-titik berdistribusi di atas dan di bawah angka 0 .

\section{Uji Hipotesis}

Analisis Regresi Linear Berganda

Tabel 9. Analisis Regresi Linear Berganda

\begin{tabular}{|l|c|c|c|c|c|}
\hline \multirow{2}{*}{ Model } & \multicolumn{2}{|c|}{$\begin{array}{c}\text { Unstandardized } \\
\text { Coefficients }\end{array}$} & $\begin{array}{c}\text { Unstandardized } \\
\text { Coefficients }\end{array}$ & \multirow{2}{*}{ Sig. } \\
\cline { 1 - 5 } & $\mathbf{B}$ & Std. Error & Beta & & \\
\hline (Constant) & 15,543 & 3,298 & & $4,7130,000$ \\
\hline Penerapan PSAK No. 45 & 0,258 & 0,089 & 0,449 & $2,8950,007$ \\
\cline { 1 - 4 } $\begin{array}{l}\text { Ketepatwaktuan Penyampaian Laporan } \\
\text { Keuangan }\end{array}$ & 0,336 & 0,154 & 0,337 & $2,1760,038$ \\
\hline
\end{tabular}

Dependent Variable: Akuntabilitas Laporan Keuangan

Sumber: Data primer diolah, 2021

Menurut hasil uji tersebut, dapat disimpulkan persamaan regresi $\mathrm{Y}=15,543+0,258 \mathrm{X} 1+0,336 \mathrm{X} 2$. Maka dapat dijelaskan bahwa penerapan PSAK No. 45 memiliki pengaruh signifikan terhadap akuntabilitas laporan keuangan dengan koefisien 0,258, dan ketepatwaktuan penyampaian laporan keuangan juga memiliki pengaruh signifikan terhadap akuntabilitas laporan keuangan dengan koefisien 0,338.

\section{Uji T}

Tabel 10. Uji T

\begin{tabular}{|l|c|c|c|c|c|}
\hline \multirow{2}{*}{ Model } & \multicolumn{2}{|c|}{$\begin{array}{c}\text { Unstandardized } \\
\text { Coefficients }\end{array}$} & $\begin{array}{c}\text { Unstandardized } \\
\text { Coefficients }\end{array}$ & \multirow{2}{*}{ Sig. } \\
\cline { 2 - 5 } & $\mathbf{B}$ & Std. Error & Beta & & \\
\hline (Constant) & 15,543 & 3,298 & & $4,7130,000$ \\
\hline Penerapan PSAK No. 45 & 0,258 & 0,089 & 0,449 & $2,8950,007$ \\
\hline $\begin{array}{l}\text { Ketepatwaktuan Penyampaian Laporan } \\
\text { Keuangan }\end{array}$ & 0,336 & 0,154 & 0,337 & $2,1760,038$ \\
\hline
\end{tabular}

Dependent Variable: Akuntabilitas Laporan Keuangan

Sumber: Data primer diolah, 2021

Menurut hasil dari uji T, dapat kita simpulkan bahwa penggunaan PSAK No. 45 berdampak positif dan signifikan pada akuntabilitas laporan keuangan. Hal ini dikarenakan nilai signifikansinya $0,007<0,05$, dan nilai t hitung 2,895>2,048 pada t tabel. Sedangkan ketepatwaktuan penyampaian laporan keuangan memiliki dampak positif dan signifikan pada akuntabilitas laporan keuangan, sebab nilai signifikansinya $0,038<0,05$ dan nilai thitung 2,176>2,048 pada t tabel. 


\section{Uji F}

Tabel 11. Uji F

\begin{tabular}{|l|c|c|c|c|c|}
\hline \multicolumn{1}{|c|}{ Model } & $\begin{array}{c}\text { Sun of } \\
\text { Square }\end{array}$ & Df & $\begin{array}{c}\text { Mean } \\
\text { Square }\end{array}$ & F & Sig. \\
\hline Regression & 99,756 & 2 & 49,878 & 10 & 0,00 \\
& & & & 5 & 0 \\
& & & & 57 & \\
\hline Residual & 128,631 & 28 & 4,594 & & \\
\hline Total & 228,387 & 30 & & & \\
\hline
\end{tabular}

Sumber: Data primer diolah, 2021

Berdasarkan hasil uji $\mathrm{F}$ di atas bisa dikatakan jika nilai signifikansi $0,000<0,05$ dan nilai F hitung 10,857 > 3,33 F tabel. Maka dari itu, bisa dikatakan jika variabel independen berdampak signifikan terhadap variabel dependen pada saat yang bersamaan atau secara simultan.

\section{Uji Koefisien Determinasi (R2)}

Tabel 12. Uji Koefisien Determinasi

\begin{tabular}{|c|c|c|c|c|}
\hline $\begin{array}{c}\text { Mode } \\
\mathbf{I}\end{array}$ & $\mathbf{R}$ & $\begin{array}{c}\boldsymbol{R} \\
\text { square }\end{array}$ & $\begin{array}{c}\text { Adjusted } \boldsymbol{R} \\
\text { Square }\end{array}$ & $\begin{array}{c}\text { Std. error of } \\
\text { the Estimate }\end{array}$ \\
\hline 1 & 0,66 & 0,437 & 0,397 & 2,143 \\
\hline
\end{tabular}

Sumber: Data primer diolah, 2021

Berdasarkan tabel tersebut terlihat jika nilai $r$-square adalah 0,437. Dapat disimpulkan jika variabel penerapan PSAK No. 45 dan ketepatwaktuan penyampaian laporan keuangan berdampak pada akuntabilitas laporan keuangan sebesar 43,7\%, dan $60,3 \%$ disebabkan faktor lain.

\section{PEMBAHASAN}

\section{Pengaruh Penerapan PSAK No. 45 Terhadap Akuntabilitas Laporan Keuangan}

Hasil hipotesis menemukan bahwa PSAK No. 45 berdampak positif pada akuntabilitas laporan keuangan, dan dapat disimpulkan bahwa H1 diterima. Artinya untuk meningkatkan akuntabilitas laporan keuangan, organisasi nirlaba perlu menerapkan PSAK No. 45 sebagai standar pengelolaan keuangannya. Informasi yang terkandung pada laporan keuangan dapat lebih lengkap dan terstruktur. Hal ini berhubungan dengan Teori Kepatuhan, kepatuhan yayasan tergolong tinggi karena patuh dalam hal penerapan standar akuntansi PSAK 45 pada penyusunan laporan keuangannya, sehingga dapat mewujudkan akuntabilitas. Dengan mendasarkan teori kepatuhan, kepatuhan terhadap standar akuntansi membuat laporan keuangan yang dihasilkan berkualitas. Teori kepatuhan membuat seseorang patuh terhadap peraturanperaturan yang berlaku. Kepatuhan dalam menerapkan standar akuntansi akan membuat laporan keuangan lebih relevan dan andal, sehingga membuat laporan keuangan lebih akuntabel. Penelitian ini didukung dengan penelitian yang telah dilakukan oleh_(Rusdiyanto, 2016) dan penelitian (Suryani, Dewi, \& Herawati, 2017) bahwa penerapan PSAK No. 45 memiliki pengaruh terhadap akuntabilitas laporan keuangan.

Pengaruh Ketepatwaktuan Penyampaian Laporan Keuangan Terhadap Akuntabilitas Laporan Keuangan

Hasil uji hipotesis menemukan bahwa ketepatwaktuan penyampaian laporan 
keuangan berdampak positif pada akuntabilitas laporan keuangan, dan dapat disimpulkan bahwa H2 diterima. Hasil dari penelitian menunjukkan bahwa untuk meningkatkan akuntabilitas laporan keuangan, maka penyusunan dan penyampaian laporan keuangan harus tepat waktu atau tidak boleh melebihi tenggat waktu yang telah ditentukan. Hal ini berhubungan dengan Teori Kepatuhan, kepatuhan yayasan tergolong tinggi dalam hal kepatuhan menyampaikan laporan keuangan tepat waktu, sehingga dapat mewujudkan akuntabilitas. Dengan mendasarkan teori kepatuhan, maka kepatuhan dalam menyampaikan laporan keuangan yang tepat waktu akan mewujudkan tanggung jawab dan berguna bagi pemakai laporan keuangan, maka organisasi nirlaba harus menyerahkan laporan keuangan secara tepat waktu. Penelitian ini didukung dengan penelitian _Indrarini \& Nanda, 2017) dan penelitian_(Suparwan, Sujana, \& Yuniarta, 2018) bahwa ketepatwaktuan penyampaian laporan keuangan memiliki pengaruh terhadap akuntabilitas laporan keuangan.

\section{Kesimpulan}

\section{KESIMPULAN}

Penelitian dilakukan di 31 yayasan sosial yang berada di Kabupaten Bantul, Kabupaten Sleman, Kabupaten Kulonprogo, dan Kotamadya Yogyakarta. Menurut hasil penelitian tersebut bisa disimpulkan bahwa penerapan PSAK No. 45 berpengaruh positif terhadap akuntabilitas laporan keuangan, dan ketepatwaktuan penyampaian laporan keuangan berpengaruh positif terhadap akuntabilitas laporan keuangan. Penerapan standar akuntansi tersebut membuat laporan keuangan menjadi lebih terstruktur dan lengkap, serta laporan keuangan dapat digunakan sebagai pengambilan keputusan jika disampaikan tepat waktu. Sehingga, jika PSAK No. 45 dan ketepatwaktuan penyampaian laporan keuangan sudah diterapkan dengan baik, akuntabilitas juga akan semakin membaik.

\section{Saran}

Saran peneliti untuk penelitian berikutnya adalah peneliti selanjutnya diharapkan menambah variabel lain yang akan diteliti dan diharapkan dapat memperbanyak sampel penelitian. Selain itu, untuk setiap organisasi nirlaba diharapkan selalu menerapkan standar akuntansi yang berlaku untuk menyusun pelaporan keuangannya, dan selalu menyampaiakan laporan keuangan tersebut secara tepat waktu.

\section{REFERENSI}

Anand, D. (2018). Penerapan Penyusunan Laporan Keuangan Yayasan Berdasarkan PSAK 45. Jurnal Kajian Akuntansi, 02(02), 160-177. doi:http://dx.doi.org/10.33603/jka.v2i2.1745

Athifah, Bayinah, \& Bahri. (2018). Pengaruh Akuntabilitas Publik dan Transparansi Laporan Keuangan Terhadap Kepercayaan Donatur pada Yayasan PPPA Daarul Qur'an Nusantara. Perisai, $2(1), \quad$ 54-74. doi:http://doi.org/10.21070/perisai.v2i1.1496

Ghozali, I. (2018). Aplikasi Analisis Multivariate dengan Program IBM SPSS 25. Semarang: Badan Penerbit Universitas Diponegoro.

Hatta, Z. M. (2021). Analisis Penerapan Akuntansi Keuangan Pada Masjid Paripurna di Pekanbaru. Jurnal Al-Iqtishad Edisi 17, 1(1), 1-15. doi:http://dx.doi.org/10.24014/jiq.v17i1.11553

Dewan Standar Akuntansi Keuangan IAI. (2011). Pernyataan Standar Akuntansi Keuangan No. 45 (revisi 2011) Pelaporan Keuangan Entitas Nirlaba. Jakarta. 
Indrarini, \& Nanda. (2017). Transparansi Dan Akuntabilitas Laporan Keuangan Lembaga Amil Zakat: Perspektif Muzaki Upz Bni Syariah. AKRUAL: Jurnal Akuntansi, 8(02), 166-178. doi:http://dx.doi.org/10.26740/jaj.v8n2.p65-77

Lewis, \& Sitompul. (2021). Pengaruh Kualitas Produk, Harga, Brand Trust dan Kualitas Pelayanan Terhadap Kepuasan Konsumen di CV Mitra Matra Mandiri Pekanbaru. Jurnal Akuntansi, Kewirausahaan, dan Bisnis, 6(1), 112-121. Retrieved from http://www.ejournal.pelitaindonesia.ac.id/ojs32/index.php/KURS/article/view/137 0

Lusdiani, \& Ta'dung. (2020). Dana Desa: Paradoks Dalam Mewujudkan Akuntabilitas Keuangan. Jurnal Economics, 8(1), 186-198. Retrieved from https://ojs.unm.ac.id/economix/article/view/14265

Mardiasmo. (2018). Akuntansi Sektor Publik. Jakarta: Penerbit ANDI.

Marfuah, Sakilah, \& Prasetyo. (2021). Faktor Determinan Ketepatan Waktu Penyampaian Laporan Keuangan Perusahaan Pertambangan di Indonesia. Wahana Riset Akuntansi, 9(1), 80-90. doi:https://doi.org/10.24036/wra.v9i1.111864

Marlinah, \& Ibrahim. (2018). Penerapan Laporan Keuangan Organisasi Nirlaba Berdasarkan PSAK No. 45. AkMen Jurnal Ilmiah, 15(1), 170-188. doi:https://doi.org/10.37476/akmen.v15i1.196

Megasiwi, I. A., \& Adi, P. H. (2020). Faktor-Faktor yang Mempengaruhi Keterandalan dan Ketepatwaktuan Pelaporan Keuangan Pemerintah Daerah. Jurnal Akuntansi Bisnis, 13(1), 33-49. doi:http://dx.doi.org/10.30813/jab.v13i1.1898

Nurmiati. (2016). Faktor-faktor yang Mempengaruhi Ketepatan Waktu Pelaporan Keuangan. KINERJA: Jurnal Ekonomi dan Manajemen, 13(2), 166-182. doi:http://dx.doi.org/10.29264/jkin.v13i2.829

Rusdiyanto. (2016). Penerapan PSAK No. 45 Pada Laporan Keuangan Yayasan Pondok Pesantren Al-Huda Sendang Pragaan Sumenep Madura untuk Mewujudkan Akuntabilitas Keuangan. GEMA Ekonomi, 05(01), 66-74.

Senyum Kita Foundation. (2018, January 18). Laporan Tahunan YSK 2016-2017.

Retrieved Mei 2, 2020, from Senyum Kita Fondation:

http://senyumkita.com/laporan-tahunan-ysk-2016-2017/

Setiawan, Rahman, \& Hidayati. (2021). Analisis Penerapan PSAK No. 45 sebagai Perwujudan Amanah dan Akuntabilitas pada Laporan Keuangan Masjid Al Akbar Surabaya. Equity Jurnal Akuntansi, 1(2), 119-126. doi:10.46821/equity.vli2.180

Sucipto, \& Noor. (2019). Pengaruh Penerapan IFRS, Terhadap Ketepatan Penyampaian Laporan Keuangan Pada Perusahaan Manufaktur di BEI Tahun 2014-2017. Jurnal Akuntansi Multidimensi (JAMDI), 2(2), 112-118. doi:http://dx.doi.org/10.96964/jamdi.v2i1.117

Sugiyono, S. (2019). Metode Penelitian Kuantitatif Kualitatif Dan R\&D. Bandung: CV Alphabeta.

Sulistiana, D. (2018). Peningkatan Akuntabilitas Publik Melalui Sistem Informasi Akuntansi pada Pondok Pesantren Salafiyah. Akuntabilitas: Jurnal Ilmu Akuntansi, 12(2), 237-248. doi:https://doi.org/10.15408/akt.v12i2.9662

Sunardi, Ambarwati, Rusmawati, Riszaldi, \& Krisnanto. (2021). Sosialisasi Pelaporan Keuangan Yayasan Sesuai PSAK 45 Tentang Laporan Keuangan Entitas Nirlaba Yayasan Pembangunan Masyarakat Sejahtera (YPMS) Pamulang Tangerang Selatan. Jurnal Pengabdian Kepada Masyarakat, 2(2), 363-369. doi:http://dx.doi.org/10.32493/al-jpkm.v2i2.10512

Suparwan, Sujana, \& Yuniarta. (2018). Pengaruh Kewajaran Penyajian Laporan Keuangan Terhadap Kualitas Akuntabilitas Keuangan Pada Dinas-Dinas Kabupaten Bangli. 
Owner: Riset \& Jurnal Akuntansi

e-ISSN : 2548-9224 |p-ISSN : 2548-7507

Volume 5 Nomor 2, Agustus 2021

$\begin{array}{llll}\text { JIMAT (Jurnal Ilmiah Mahasiswa Akuntansi), } & \text { 8(2). }\end{array}$ doi:http://dx.doi.org/10.23887/jimat.v8i2.13275

Suryani, Dewi, \& Herawati. (2017). Pengaruh Penerapan PSAK No. 45, Kompetensi Sumber Daya Manusia dan Sistem Pengendalian Internal Terhadap Kualitas Laporan Keuangan Yayasan Sosial Se-Kabupaten Buleleng. JIMAT (Jurnal Ilmiah Mahasiswa Akuntansi) Undiksha, 8(02). doi:http://dx.doi.org/10.23887/jimat.v8i2.14655

Zahavy, \& Leonenko. (2019). An Accountability Account? The Diserve Qutcomes of Prerceived Personal and Team Accountability. Journal Academy Of Management. doi:https://doi.org/10.5465/AMBPP.2019.222 